\title{
Crise venezuelana, emigração e fechamento de fronteira: análise da Ação Cível Originária n. ${ }^{\circ}$ 3121/RR
}

\author{
Venezuelan crisis, emigration and the closure of borders: an analysis of the Civil \\ Injunction Suit $n^{\circ} 3121 / R R$
}

\author{
Tatiana de A F R Cardoso Squeff \\ Sarah Francieli Mello Weimer
}

\section{Resumo}

Considerando a frágil situação em que a Venezuela se encontra, um êxodo populacional está em curso na tentativa única de fazer com que os direitos fundamentais de seus jurisdicionados, então ameaçados naquele país, restem assegurados. $\mathrm{E}$ entre os países de destino está o Brasil. Diante disso, a presente pesquisa tem como objetivo central debater a legalidade em torno do fechamento da fronteira brasileira com a Venezuela em Roraima, realizado em 2018, com base na justificativa do governo de Roraima de que, diante do influxo massivo de migrantes oriundos daquele país, essa seria a única medida disponível a ser tomada para se evitar a desordem na região. Para tanto, traça-se primeiramente as origens do êxodo populacional em direção ao Brasil, na tentativa de esclarecer o contexto político-social no qual a dita crise migratória estaria inserida, de modo a averiguar a veracidade desse argumento roraimense. Posteriormente, destacam-se os desdobramentos judiciais do influxo de venezuelanos no Brasil, particularmente a propositura da Ação Civil Originária (ACO) n. ${ }^{\circ} 3121$ por Roraima e, consequentemente, o posicionamento do Poder Judiciário, especialmente no que tange ao indeferimento da referida ação. Logo, metodologicamente, realiza-se uma pesquisa de natureza aplicada no âmbito das Ciências Jurídicas e Sociais, notadamente do Direito Constitucional e Direito Internacional Privado, utilizando-se, quanto à abordagem, do método dedutivo e, quanto aos objetivos, dos métodos descritivo e explicativo. Partindo-se, portanto, de uma pesquisa qualitativa, utilizando-se majoritariamente os procedimentos bibliográfico e documental, além do próprio estudo de caso, em uma perspectiva pragmática, no que se refere à situação venezuelana.

Palavras-chave: Venezuela. ACO n. ${ }^{\circ} 3121 /$ RR. Migração. Fronteira brasileira. Roraima.

\section{Abstract}

Considering the fragile situation in which Venezuela finds itself in, a population exodus is underway in the sole attempt to ensure that the fundamental rights of those insered within its jurisdictions, therein threatened, are secured. And among the countries of destination is Brazil. Given this scenario, the main objective of this research is to debate the legality surrounding the 2018 closure of the Brazilian border in Roraima with Venezuela, based on the fact that this state is facing a massive influx of migrants from that country, and that the only measure available to be taken to avoid disorder in the region is closing the border. Thus, the origins of the population exodus to Brazil are firstly traced in this paper, in an attempt to clarify the political and social context surrounding the existing migratory crisis, in order to ascertain the veracity of this argument. Secondly, the judicial developments of the influx of Venezuelans in Brazil, particularly the filing of the Civil Injunction Suit (CIS) n. 3121 by the State of Roraima and the position of the Judiciary, especially regarding the rejection of said action, are explained. Methodologically, it should be stressed that this is a research of an applied nature in the scope of the Legal and Social Sciences, especially regarding Constitutional and Private International Law. Regarding the approach, the deductive method is used, and concerning the objectives, a descriptive and explanatory approach is used. Besides of the case study procedure regarding the Venezuelan situation, to be examined through a pragmatic perspective, the sources are to be collected through a qualitative research, using mostly bibliographic and documentary procedures.

Keywords: Venezuela. CIS n. 3121/RR. Migration. Brazilian Border. Roraima.

Doutora em Direito Internacional pela UFRGS, com período sanduíche na Universidade de Ottawa. Mestre em Direito Público pela Unisinos, com pesquisa junto à Universidade de Toronto e bolsa CAPES/DFAIT. Especialista em Relações Internacionais Contemporâneas e em Direito Internacional - ambas pela UFRGS, e em Língua Inglesa pela Unilasalle. Professora Permanente do Programa de Pós-Graduação em Direito e Professora Adjunta de Direito Internacional da Universidade Federal de Uberlândia - UFU. Co-coordenadora do Grupo de Estudos e Pesquisa em Direito Internacional - GEPDI/UFU, registrado no CNPq. Uberlândia - MG - Brasil. E-mail: tatiafrcardoso@gmail.com. ORCID Id: http://orcid. org/0000-0001-9912-9047.

Mestra em Direito pela UFRGS. Mestranda em Ciência Política pela UFRGS. Bacharel em Direito pela UniRitter. Advogada. Porto Alegre - RS Brasil. E-mail: sarah.weimer@hotmail.com. ORCID Id: http://orcid.org/0000-0002-3004-6160. 


\section{Introdução}

No ano de 2018, diversas publicações jornalísticas anunciavam que cerca de 30 mil venezuelanos haviam se estabelecido no Brasil como resultado parcial de um fluxo migratório que se intensificou no período entre 2015 e $2018 .{ }^{1}$ Esse impactante e volumoso dado chama ainda mais a atenção se observado comparativamente: no ano de 2015, estima-se que apenas mil venezuelanos viviam no país (BRASIL, 2018a), ao passo que, segundo a projeção feita pelo Instituto Brasileiro de Geografia e Estatística (IBGE), até o ano de 2022, esse número pode chegar a quase 80 mil (BRASIL, 2018b).

A isto soma-se o fato de que o ingresso de cidadãos venezuelanos em território brasileiro ocorre quase que exclusivamente pelo estado de Roraima, especificamente pelo exíguo município de Pacaraima (BRASIL, 2018a), bem como por Boa Vista. A chegada massiva de venezuelanos pela cidade roraimense causou conflitos na região em razão da precária estrutura existente para receber os recém-chegados.

Diante desse cenário, o governo do estado de Roraima, em 13 de abril de 2018, ajuizou a Ação Cível Originária n. ${ }^{0} 3121$ no Supremo Tribunal Federal (STF), que, em pedido de tutela provisória, postulou que a União decidisse pelo fechamento temporário da fronteira do Brasil com a Venezuela, a fim de barrar a entrada desordenada de venezuelanos no estado e, assim, frear o incalculável impacto econômico que o estado estaria suportando em razão do intenso fluxo desses migrantes, segundo afirma a parte autora (STF, 2018).

Por seu turno, a ação ajuizada teve grande repercussão. Argumentos favoráveis e contrários ao pedido mobilizaram-se pelo país, tanto em organizações que atuam na defesa dos direitos humanos quanto em debates acadêmicos sobre a viabilidade jurídica e os impactos sociais. E isto convidou não só o Supremo, mas também a sociedade para pensar sobre o enfrentamento da crise migratória venezuelana, o alcance e prevalência (ou não) dos Direitos Humanos e dos valores humanitários e, ainda, sobre o conflito entre um Estado membro e a União.

Em vista disso, o presente texto cuida de apresentar o desenlace da Ação Cível Originária n. ${ }^{\circ} 3121 /$ RR no campo jurídico, com os andamentos e decisões oriundas do STF, como também busca compreender e acompanhar os desdobramentos da crise migratória e seus impactos na sociedade brasileira, com vista a construir um quadro geral da situação dos migrantes venezuelanos no país.

\section{A crise venezuelana e o êxodo populacional do Estado: a escalada do problema e seus reflexos no território brasileiro}

A fim de que seja possível debater o pedido de fechamento da fronteira do estado de Roraima e os argumentos jurídicos que (des)amparam tal requerimento, mostra-se necessário averiguar, primeiramente, o motivo pelo qual os venezuelanos deslocam-se em direção ao Brasil. Afinal, por força do crescente influxo, as tensões na região de fronteira (Pacaraima/RR-Brasil e Santa Elena de Uairén/Gran SabanaVenezuela) acirraram-se, fazendo emergir não só o questionamento acerca da possibilidade jurídica da realização de tal ato em direito interno e internacional, como também da própria propositura do pleito por parte do ente federado diretamente implicado.

\section{a. Contexto político-social da crise migratória venezuelana}

Em apenas dois anos, entre 2015 e 2016, o percentual de pessoas abaixo linha da pobreza ultrapassou os $80 \%$, isto é, somente $20 \%$ da população venezuelana não se encontram em situação de pobreza extrema, conforme mostram os dados do relatório da Encuesta sobre Condiciones de Vida em Venezuela - ENCOVI, de 2016, realizado de maneira independente com o apoio de organizações não governamentais

Ao pesquisar as seguintes palavras: "venezuelanos", "Brasil" e "migração" em sites de busca (como o Google), encontra-se muitas reportagens e notícias de jornais eletrônicos, como os publicados pela British Broadcasting Corporation - BBC News Brasil, pelo El País, pelo editorial O Globo e pela Empresa Brasil de Comunicação - EBC, entre outros, que constantemente tratam do intenso fluxo migratório da Venezuela para o Brasil e também de seus desdobramentos. 
(ONGs) e universidades (ESPAÑA, 2017). Embora esse dado estarrecedor venha acompanhado de muitas inquietações, este trabalho se ocupa de responder uma delas: quais as possíveis causas político-sociais que possibilitaram que a Venezuela chegasse a este ponto?

Com o objetivo de melhor compreender como a conjuntura se desenrolou, parte-se da premissa de que, apesar de ser o país com a maior reserva de petróleo do mundo, a Venezuela tem na exploração dessa riqueza um dos vetores da dramática crise em que está inserida. Nesse viés, Fernando Coronil aponta que, durante os períodos ditatoriais ${ }^{2}$ que marcaram o país no século $X X$, houve grande incremento do petróleo na economia, e, paralelamente, uma opção desses governos de não fomentar o desenvolvimento da agricultura e da indústria. Essas escolhas acabaram por colocar o petróleo em papel de destaque, e associaram sua exploração à imagem de uma Venezuela democrática e moderna, distante do passado colonial, estabelecendo os pilares daquilo que Coronil denominou de criação do Estado mágico. ${ }^{3}$

Na perspectiva do autor, a narrativa de exaltação dessa imagem (Estado venezuelano moderno e democrático), tinha por fim ocultar as continuidades que atravessavam o país desde a sua constituição como petroestado, na década de 1930, quando se passou a imaginar a Venezuela como uma grande nação petroleira, próspera e moderna, ao mesmo tempo em que se fortalecia a associação da figura do presidente ao Estado, e este último, por sua vez, mais e mais identificado como o agente dessa modernização (CORNIL, 2013, p. 182-186). E, assim, não apenas o monopólio da violência cabia ao Estado, mas também a exploração da sua maior riqueza natural.

Nessas circunstâncias foram estabelecidas as bases de um Estado e um sistema político em que os confrontos políticos e a luta de classes ocorriam principalmente em torno do acesso ao Estado, que era tido como aquele capaz de solucionar todos os problemas e, ainda, garantir o progresso e a abundância para a sociedade. Todavia, esse Estado mágico resta abalado com a chegada do ajuste neoliberal que o governo de Carlos Andrés Peréz firmou com o Fundo Monetário Internacional (FMI), consolidando a crise do projeto populista que marcava a relação povo e Estado desde 1936 (CORNIL, 2013, p. 406).

Ao longo da década de 90 , sob o regime neoliberal, as condições de vida dos setores populares se tornaram cada vez mais precárias e a polarização entre a minoria privilegiada e a maioria empobrecida se intensificou, resultando em insurgências populares contra o sistema, tais como a tentativa de golpe de estado pela operação Zamora, comandada por Hugo Chávez, em 1992, e, também, o juízo político do então presidente, Andrés Pérez, no ano seguinte. Com o processamento do impeachment, o governo interino chamou novas eleições e, assim, Rafael Caldera Rodrigues chegou ao comando do Poder Executivo. Nesse governo, a crise econômica venezuelana se instaura com a baixa na exportação do petróleo e a sociedade reforça o rechaço às políticas neoliberais.

Diante desse cenário, ascende a imagem de Hugo Chávez, que, filiado ao Movimento da Quinta República, disputa as eleições de 1998. Como apontam Karl Schurster e Rafael Araujo, ${ }^{4}$ a campanha eleitoral chavista apoiava-se no tripé refundação da Venezuela, antineoliberalismo e combate à pobreza, indo ao encontro do descontentamento da sociedade, que o elege naquele mesmo ano (SCHURSTER; ARAUJO, 2015, p. 18). E, assim, em 1999, tem início o governo de Hugo Chávez, chamado de Era de Chávez, que permanece no Poder por quatorze anos.

O novo governo de imediato estabelece mudanças. Em 2000, o presidente consegue aprovar uma nova Constituição, que transformaria o país em República Bolivariana ${ }^{5}$ da Venezuela. Consoante André Souza, a

2 No século XX, compreende-se que a Venezuela esteve sob ditadura durante o governo dos generais Juan Vicente Gómez (1908-1935) e Marcos Pérez Jiménez (1952-1958) e também no primeiro governo de Carlos Andrés Pérez (1974-1979).

3 Na teoria de Fernando Coronil (2013), a exploração do petróleo pelo Estado e a associação deste como o propulsor da modernização contribuíram para a edificação do petroestado, ou seja, a Venezuela como a grande nação do petróleo, produzindo, tanto na sociedade quanto nas instituições, a ideia de um Estado mágico, em que imperaria a bonança e que todas as faltas seriam supridas pela abundância do petróleo.

4 Os autores Karl Schurster e Rafael Araujo são também organizadores do livro "A Era Chávez e a Venezuela no tempo presente", lançado em 2015, e conta com quatorze artigos de professores, de diversas instituições de ensino do Brasil e da Venezuela, que discutem tanto questões institucionais, crises representativas e sobre o agir político quanto sobre a dinâmica institucional e a nova ordem política da Venezuela, baseada em interesses regionais atinentes ao petróleo e à política externa.

5 A expressão "bolivariana" corresponde a uma homenagem e inspiração na doutrina e prática de Simon Bolívar, militar e líder político que conduziu a Venezuela em seu processo de independência da Espanha colonizadora. 
transformação do Poder Legislativo até então bicameral em unicameral, o estabelecimento de eleições para o cargo de juízes e o esvaziamento do sistema bipartidário são algumas modificações trazidas pelo novo Texto (SOUZA, 2015, p. 53). Mas talvez a mais importante alteração tenha sido a previsão constitucional de novas eleições para o mesmo ano, com mandatos mais extensos, de 4 para 6 anos - o que, na prática, resultou em nova vitória de Chávez, dessa vez com maioria no Parlamento.

Embora a oposição tenha por diversas vezes articulado a retirada do presidente eleito, ${ }^{6}$ ele permaneceu no poder até o ano de 2013. O governo chavista foi marcado pela promoção de melhorias na qualidade de vida dos venezuelanos, especialmente para as classes mais pobres, tendo o desemprego caído de $14,5 \%$ para $8 \%$ e o produto interno bruto (PIB) per capta aumentado de US $\$ 8.2$ mil para US\$13.2 mil (CURY, 2013).

Ademais, essa época também resta conhecida pela promulgação de legislações ${ }^{7}$ que objetivavam concretizar suas promessas de campanha. Entre elas, leis que permitiam ao Estado interferir diretamente no mercado privado, impondo restrições ao desenvolvimento da pesca industrial e limitando a propriedade privada com vistas à realização da reforma agrária.

Contudo, mesmo em meio a turbulências sociais, políticas e econômicas, especialmente nos anos de 2002 e 2003, quando houve a paralisação da principal fonte econômica do Venezuela, a produção do petróleo, Hugo Chávez aumentava cada vez mais sua popularidade, a ponto de ter capital político suficiente para nacionalizar o petróleo (RIBEIRO, 2015, p. 266) com o apoio das Forças Armadas e de grande parcela da população.

Tendo em conta a escolha feita pelos governos venezuelanos desde o início do século passado, focando quase que exclusivamente na produção de petróleo, sem desenvolver a indústria ou a agricultura, evidencia-se a imbricada dependência do Estado com o produto. Segundo Ribeiro, apesar da Venezuela dispor de grandes reservas petroleiras, o principal destino do produto é a exportação, por isso tem o preço do seu barril condicionado pelo mercado mundial.

A nacionalização do petróleo, em 2003, embora tenha proporcionado a aplicação da arrecadação oriunda do petróleo em programas sociais, se sustentou apenas em razão dos altos preços com que os barris eram vendidos no mercado internacional. Desse modo, com um programa de distribuição de renda por meio de políticas públicas diretamente dependentes do mercado, a promoção de bem-estar social do país também passa a estar condicionada à balança internacional.

Assim, Ribeiro alerta que, para que os indicadores socioeconômicos da Venezuela estivessem em alta, também os preços dos barris deveriam estar elevados, mas quando os valores despencavam, as ameaças inflacionárias cresciam (RIBEIRO, 2015, p. 253-260). Com vista a minimizar esses efeitos, o governo passou a controlar a inflação por meio da regulação do câmbio, como resultado, ao final da Era de Chávez, a dependência econômica do petróleo ameaçava seriamente a economia em consequência da sobrevalorização cambial imposta pelo Estado.

A chegada de Nicolas Maduro à presidência da Venezuela ocorre após o falecimento de Hugo Chávez, que havia vencido as últimas eleições e indicado Maduro como seu sucessor. Embora tivesse conquistado a terceira reeleição consecutiva, o seu partido obteve a menor adesão nas eleições para o Legislativo desde o início da Era Chavista, evidenciando maior articulação da oposição e prospectando mais resistência na aprovação de suas pautas.

Diante desse cenário, Nicolas Maduro obtém a vitória em um processo eleitoral envolvo em suspeitas e fortemente questionado pela oposição, como noticiado pela mídia internacional. ${ }^{8}$ Somado a isso, após sua eleição, a crise do país se agravou. Em 2014, houve grande redução no preço do petróleo mundialmente, e

\footnotetext{
Em 2002, a oposição tenta tomar o poder ao desestabilizar o governo com a conclamação de greves e violentas manifestações, mas a permanência de Chávez na presidência é reivindicada pela sociedade, em especial pelas camadas mais populares. Já em 2004, a oposição se articula institucionalmente para tentar derrubar o presidente por meio de um referendo, que acaba, mais uma vez, com a preferência do povo pela continuidade de seu governo.

Por exemplo, a Lei de Hidrocarbonetos, que aumentou a regulação e fiscalização estatal sobre a indústria petroleira, inclinando-se para reverter as privatizações que foram realizadas no setor pelos governos anteriores.

Conforme apresentou o Jornal O Globo na matéria "Herdeiro de Chávez, Maduro é eleito na Venezuela; rival não reconhece" (G1, 2013).
} 
isto, como explica Leonardo Vera (2018, p. 84), refletiu na queda da exportação e no aumento da inflação, ao passo que o PIB per capita diminuiu, não só por causa da dependência estatal da exploração desse recurso natural - que restava na casa de $90 \%$-, como também das próprias medidas adotas pelo novo presidente, como a limitação de lucros, fazendo com que os outros setores acabassem solapando a economia do país por meio da inflação estratosférica e da escassez de produtos básicos de consumo, o que, mais uma vez, reforça ainda mais a dependência do Estado ao petróleo.

Nas palavras de Vera (2018, p. 84), portanto, a catástrofe econômica venezuelana estaria fundamentada em fatores estruturais, como:

\begin{abstract}
la persistente dependencia de un recurso natural exportable cuyos ingresos exhiben un comportamiento altamente volátil, la tendencia a acumular gestiones fiscales deficitarias, el peso excesivo del Estado en la economía, el escaso dinamismo del sector privado no petrolero para proyectarse internacionalmente, la alta dependencia de las importaciones, la sobrevaluación crónica de la moneda, la caída secular de la productividad, son todos factores que se conjugan para proyectar, con un elevado grado de certeza, el advenimiento de una crisis. También puede apelarse a la caída abrupta del precio del petróleo y de los ingresos de origen petrolero como la razón que explica el advenimiento de la crisis.
\end{abstract}

A tal cenário econômico, soma-se a instabilidade política decorrente do falecimento de Chávez, seguida pela eleição de Maduro - em que pese fosse o candidato indicado por Chávez, Maduro não partilhava do mesmo tom conciliatório e tampouco da mesma popularidade que seu antecessor.

$\mathrm{O}$ atual presidente venezuelano adotou medidas excessivamente intervencionistas, determinando a redução do preço de mercadorias e limitando a margem de lucro do setor privado, o que resultou em colapso social - sem contar as recorrentes práticas violentas para coibir a expressão de insatisfação por parte da população para com o governo. André Paulo Pereira (2018) exemplifica/enumera tais problemas correntes vividos no país vizinho:

A inflação é de quatro dígitos (ultrapassou 2.500\% em 2017), a escassez de remédios supera $85 \%$, estudos recentes demonstram que seis a cada dez venezuelanos já foram dormir com fome, e a população perdeu em média $11 \mathrm{~kg}$ por falta de alimentos ou de dinheiro para comprá-los. A criminalidade se tornou uma das maiores do mundo, e a percepção das pessoas é de que vivem no país mais perigoso do mundo, segundo a Gallup, com 27.000 assassinatos em 2017, sendo 5.000 por resistência às forças de segurança.

Nessa lógica, além da hiperinflação, da desvalorização da moeda, da limitação das importações e das sanções internacionais, restou um país extremamente precarizado, com grande parcela da população vivendo abaixo da linha pobreza, ${ }^{9}$ e que, com as prateleiras vazias, com a escassez de alimentos, remédios e vacinas, viu-se imerso, também, na necessidade de emigrar, gerando mais uma crise. Diante do dramático colapso econômico, político e social da Venezuela, seus cidadãos passam a ter de buscar outros lugares para refazerem suas vidas, de modo que os países latino-americanos vizinhos recebem, a partir de 2015, grandes contingentes de venezuelanos.

Sendo o Brasil um desses destinos, observou-se que a concentração do fluxo migratório de venezuelanos em um pequeno município, a ora citada cidade de Pacaraima, situada no noroeste do estado de Roraima, exasperou a região, de modo que o governo do estado moveu uma Ação Cível Originária que, em pedido de tutela antecipada, solicitou o temporário fechamento da fronteira com o país vizinho. E, assim, suscitando questões de ordem constitucional e, também, de tratados internacionais, a ação foi circundada por polêmicas, com apoios e ataques diversos, sendo relevante para examinar a atuação do Brasil diante da crise migratória venezuelana, como se verá a seguir.

\title{
b. A crise migratória venezuelana chega ao Brasil
}

Cerca de 30 mil cidadãos venezuelanos se estabeleceram no país nos últimos quatro anos (BRASIL, 2018a). O ingresso em território brasileiro ocorre, em grande parte, pelo estado de Roraima (G1, 2018a),

\footnotetext{
9 Segundo os dados divulgados pela Encuesta sobre Condiciones de Vida em Venezuela (ENCOVI), de 2016, já citados.
} 
especificamente pelo município de Pacaraima, que fica a uma distância de 215 quilômetros da capital Boa Vista, sendo, portanto, o principal destino dos recém-chegados exatamente pela proximidade com a fronteira, ${ }^{10}$ já que são muitos os que fazem a cruzada caminhando e chegam ao Brasil sem condições financeiras de se deslocar internamente.

Os números são ainda superiores se considerados os números totais de pessoas que adentraram o território nacional para se deslocar a outras nações da América do Sul, como Argentina, Bolívia e Paraguai (MARTINS, 2018; PASSAARINHO, 2018), ou para permanecer de maneira temporária, terminando por retornar à Venezuela, após um curto período de tempo, por medo (MENDONÇA, 2018) ou por falta de oportunidades (VIEIRA, 2018). Nos últimos 17 meses (de julho de 2017 a novembro de 2018), aproximadamente 128 mil venezuelanos cruzaram a referida fronteira - e se em torno de $46 \%$ permaneceu, os demais se deslocaram (68.9 mil) ou retornaram (31.5 mil), consoante a Polícia Federal (G1, 2018a). ${ }^{11}$

Os migrantes que resolveram permanecer, até março de 2018, em sua grande maioria, optaram pelo refúgio ou pela informalidade. Consoante os dados da Polícia Federal (TOLEDO, 2016), esse número está em ascensão: em 2013, foram 54 pedidos de refúgio feitos no Brasil por venezuelanos; em 2014, o número subiu para 208 solicitações. Já no ano de 2015 foram 825 pedidos, representando um aumento de mais de $1.500 \%$. Ato contínuo, em 2016, foram 1805 solicitações, ou seja, mais do que o dobro do ano anterior.

Em 2017, de acordo com o Alto Comissariado das Nações Unidas para os Refugiados (ACNUR) e o Comitê Nacional para Refugiados (CONARE), dos 33.866 pedidos de refúgio que o Brasil recebeu, ${ }^{12}$ quase 18.000 solicitações foram de venezuelanos (BITTENCOURT, 2018; VIEIRA, 2018). Em 2018, entre janeiro e agosto, os números são ainda mais expressivos: de 48.445 pessoas que solicitaram refúgio no país, 37.607 eram venezuelanas, fazendo com que o número de pedidos em oito meses já superasse todo o ano anterior, incluindo pessoas oriundas de outras nacionalidades (VEJA, 2018).

Outrossim, como referido, outra grande parcela de indivíduos permaneceu irregularmente, fazendo com que fossem promovidas retiradas compulsórias de imigrantes (G1, 2016; TOLEDO, 2016) sem a oportunidade de regularização documental (nos termos da lei que então vigorava no Brasili3) - fato que só se tornou conhecido quando, em março de 2018, o Estado brasileiro, já sob os auspícios da nova Lei de Migração, cuja base decompõe da segurança nacional para a promoção dos direitos humanos, ${ }^{14}$ para além da possibilidade de regularização, ${ }^{15}$ flexibilizou as regras de permanência de venezuelanos no país.

Esse fato deu-se em razão da edição da Portaria Interministerial n. ${ }^{\circ} 9$, de 14 de março de 2018 (BRASIL, 2018d ), a qual não apenas supre a "lacuna deixada pelo fim da validade da Resolução n. ${ }^{\circ} 126$ do CNIg (Conselho Nacional de Imigração), publicada em março de 2017 e que era válida por um ano" acerca da possibilidade de pedido de residência temporária por parte de pessoas oriundas de países fronteiriços ao Brasil, que não sejam nacionais dos países membros do Acordo de Residência do Mercosul e países associados, mas também flexibiliza as regras para a sua solicitação (DELFIM, 2018).

Entre as mudanças - as quais favorecem os cidadãos venezuelanos -, podem-se citar a não exigência de certidão "apostilada", a gratuidade do serviço ${ }^{16}$ e a possibilidade de, após dois anos, transformar a

10 Depois de Roraima, que concentra $47 \%$ desse influxo de venezuelanos, o segundo estado que mais recebe é São Paulo (28\%). Outro destino que tem se tornado recorrente é Manaus, justamente pela falta de oportunidades encontrada em Roraima, em que pese a distância - $1.008 \mathrm{~km}$ da fronteira pela BR-174 (a mesma utilizada para chegar à Boa Vista). Em 2018, já são 3.500 pedidos de refúgio na cidade, contra 2.780 em 2017 (MAISONNAVE, 2018; MARTINS, 2018).

11 Se computados desde o início de 2017, esses números são ainda superiores: "[d]os 154 mil que cruzaram a fronteira por Roraima, 75,5 mil não registraram saída do território nacional, mas os outros 79,4 mil deixaram o país" (COSTA, 2018c).

12 Apesar do número expressivo total de solicitações no Brasil, impende ressaltar que apenas 587 solicitações foram deferidas em 2017 , em função da falta de estrutura do próprio Conare para processar as solicitações de maneira mais expedita, o qual conta com apenas 13 funcionários (MARTINS, 2018).

13 Cf. Art. 57 e seguintes do Estatuto do Estrangeiro (BRASIL, 1980).

${ }^{14}$ Cf. Art. 30: "A política migratória brasileira rege-se pelos seguintes princípios e diretrizes: I - universalidade, indivisibilidade e interdependência dos direitos humanos; (...) III - não criminalização da migração; (...) V - promoção de entrada regular e de regularização documental” (BRASIL, 2017).

15 Cf. Art. 50: “(...) § 1o A deportação será precedida de (...) prazo para a regularização não inferior a 60 dias, podendo ser prorrogado, por igual período (...)" (BRASIL, 2017).

16 Quanto ao pagamento de taxas por venezuelanos - as quais eram de $\mathrm{R} \$ 311,22$-, cumpre avultar que estas já haviam sido completamente suprimidas em agosto de 2017, forte em decisão proferida contra a União (G1, 2017). 
residência temporária regulada pela Portaria em residência por tempo indeterminado (DELFIM, 2018). Assim, o pedido, realizado na Polícia Federal, necessita ser instruído com duas fotos 3x4, cópia de documento que ateste a identidade e filiação, e declaração de ausência de antecedentes criminais dos últimos cinco anos (DELFIM, 2018).

Com isso, observou-se um grande número de pedidos para a correção do status migratório. "A Polícia Federal informou [...] que 10.079 venezuelanos deram entrada em sua regularização no país desde $1^{\circ}$ de abril [de 2018], o que equivale a $20 \%$ dos pedidos de cidadãos do país caribenho nos últimos três anos" (FOLHA DE SÃO PAULO, 2018). A instituição ainda confirmou que estavam sendo realizados, em média, 600 atendimentos diários apenas em Boa Vista (BRASIL, 2018c; FOLHA DE BOA VISTA, 2018) - isso sem contar os mais de 13.000 atendimentos já agendados (COSTA, 2018c). Por isso, além do crescente número de solicitantes de refúgio oriundos da Venezuela, existem, hoje, cerca de 14.900 venezuelanos com residência temporária no país (COSTA, 2018c).

Esses números começaram a preocupar as cidades mais afetadas, posto que, com a regularização, a dependência para com o Estado tornou-se mais evidente, passando-se a exigir uma maior prestação de serviços em prol dessa população extremamente carente. Afinal, muitos daqueles que chegam permanecem em situação de rua ${ }^{17}$ e são recorrentemente submetidos a situações abusivas (FELIX; COSTA, 2016). Além disso, há a necessidade de se criar políticas de emprego ${ }^{18} \mathrm{e}$ fornecer o direito constitucional de educação básica (FAGUNDES, 2018; MAISONNAVE, 2018), bem como o de atendimento de saúde (BRANDÃO, 2016), incluindo-se a vacinação dos migrantes, a fim de evitar surtos de doenças praticamente erradicadas no país, como o sarampo, tal como alertado pela própria Organização Mundial da Saúde (OMS) (COSTA, 2018a; CHADE, 2018).

Não só isso, com as múltiplas possibilidades de permanência, o país passou a atrair mais migrantes. Muito embora esteja acolhendo um pequeno percentual quando em comparação com os demais países da região, ${ }^{19}$ a variação do fluxo migratório de venezuelanos que adentraram o Brasil, de fato, tem aumentado exponencialmente: entre 2015 e 2018, a variação do fluxo para o Brasil foi de $+1.360 \%$, abaixo apenas do Peru (+14.975\% - país com a mais alta variação mundial), da Colômbia $(+1.686 \%)$ e do Chile $(+1.222 \%)$ (GORTÁZAR, 2018).

Ciente disso, o governo federal brasileiro editou a Medida Provisória (MP) n. ${ }^{\circ} 820$ de 2018 (transformada, posteriormente, na Lei Federal $n .^{\circ}$ 13.684) (BRASIL, 2018e), que dispõe sobre as medidas de assistência emergencial para acolhimento a pessoas em situação de vulnerabilidade decorrente de fluxo migratório provocado por crise humanitária, visando trabalhar em cooperação com o estado de Roraima no recebimento e atendimento dos venezuelanos (BRASIL, 2018f). Além disso, a referida MP "condiciona a execução das ações de assistência à disponibilidade orçamentária", muito embora torne mais céleres as formas de transferência de recursos e a contratação de serviços (ARAÚJO; MONTEIRO; RIBEIRO, 2018), assim como estabelece como "prioridade, [a] aplicação dos recursos [...] em ações e serviços de saúde e segurança pública” (BRASIL, 2018g).

Para complementar, Michel Temer assinou dois decretos sobre o tema. O primeiro, Decreto n. ${ }^{\circ} 9.285$ (BRASIL, 2018h), trata do reconhecimento da situação de vulnerabilidade dos cidadãos venezuelanos em Roraima, asseverando que a origem da situação resta na "crise política, institucional e socioeconômica observada no país vizinho ao longo dos últimos anos" e na "ruptura da ordem democrática daquele país", nos termos da "declaração assinada na Cúpula dos Chefes de Estado do Mercosul e Estados Associados em julho de 2017" (ARAÚJO; MONTEIRO; RIBEIRO, 2018).

\footnotetext{
17 "Segundo a operação Acolhida, que cuida do fluxo migratório, há mais de 2,2 mil venezuelanos em situação de rua em 11 das 15 cidades de Roraima" (COSTA, 2018c).

18 "[E]m Roraima, um levantamento da prefeitura de Boa Vista apontou que só na capital há 25 mil moradores venezuelanos - o equivalente a 7,5\% da população local, que é de 332 mil habitantes. Desses, pelos 65\% estão desempregados" (G1, 2018a).

19 Importa avultar que o Brasil recebe apenas $2 \%$ dos cerca de 2,3 milhões de venezuelanos que emigraram em razão da crise até julho de 2018 , de modo que é incorreto afirmar que o Brasil é o país que mais recebeu imigrantes oriundos desse país, em que pese a grande "comoção" da mídia. Até julho de 2018, os países que mais receberam Venezuelanos na América do Sul foram: Colômbia (900 mil), Equador (500 mil), Peru (350 mil), Chile (105 mil) e Argentina (95 mil) - números aproximados (PASSAARINHO, 2018; O GLOBO, 2018).
} 
Já o segundo documento, o Decreto n. ${ }^{\circ} 9.286$ (BRASIL, 20180), trata da criação do Comitê Federal de Assistência Emergencial para o acolhimento de pessoas em situação de vulnerabilidade decorrente do fluxo migratório venezuelano, composto por 12 ministérios, os quais terão que repassar verbas de seus orçamentos ${ }^{20}$ para a realização de ações para o acolhimento de venezuelanos.

\begin{abstract}
O texto prevê que Comitê [deve ser] presidido pela Casa Civil, mas [tem] um representante das pastas da Justiça e Segurança Pública; Defesa; Relações Exteriores; Educação; Trabalho; Desenvolvimento Social; Saúde; Planejamento; Integração Nacional; Direitos Humanos, e Gabinete de Segurança Institucional da Presidência da República. O Ministério da Defesa atua [...] como Secretaria-Executiva do Comitê e prestará apoio administrativo a ele. Além disso, cabe [...] ao Ministério da Defesa a operacionalização e, se necessário, a execução das despesas relativas a reuniões do grupo [realizadas, "em caráter ordinário, com periodicidade mínima mensal e, em caráter extraordinário, sempre que houver necessidade, por meio de convocação de seu Presidente"] (ARAÚJO; MONTEIRO; RIBEIRO, 2018).
\end{abstract}

E foi por meio dessas medidas (PARAGUASSU, 2018), somadas à edição de três decretos autorizando o emprego específico das Forças Armadas para a Garantia da Lei e da Ordem (GLO) no estado de Roraima (BRASIL, 2018k; BRASIL, 2018I; BRASIL, 2018m), que restou incumbido ao Ministério da Defesa, por meio do Exército, Marinha e Aeronáutica, a acolhida de migrantes venezuelanos naquele estado. Essa medida foi tratada como negativa por muitos, exatamente pela utilização de militares para auxiliar no acolhimento, particularmente pela potencial mensagem de inacessibilidade ao Brasil que ela poderia trazer consigo, ${ }^{21}$ bem como pela inexistência de treinamento específico desses indivíduos para lidar com o acolhimento de pessoas (COSTA, 2018b; MARTINS, 2018).

Deve-se, portanto, desmistificar a negatividade em torno da adoção dessa medida. Ao visitar-se o centro de acolhimento de Boa Vista in loco, ${ }^{22}$ nota-se que o trabalho desempenhado pelas Forças Armadas é muito positivo, não só por agrupar os atendimentos em um mesmo local, onde são fornecidos a alimentação inicial, o acompanhamento médico, as vacinas e os documentos de identidade e trabalho de maneira expedida, como também por serem indicados abrigos para residência temporária (os quais são mantidos e/ou administrados pelo Exército com a colaboração de diversas agências internacionais, como o ACNUR, e organizações não governamentais, como a Fraternidade Internacional e a Avsi) e pela promoção da interiorização. ${ }^{23}$

Apesar disso, essas medidas não se mostram suficientes para lidar com a quantidade de indivíduos que adentram o território nacional, de modo que algumas localidades, particularmente no estado de Roraima, veem-se em situação de emergência (JORNAL NACIONAL, 2018b; AGENCE FRANCE-PRESSE, 2018c), exigindo do governo federal que, para além das medidas adotadas, outras sejam arquitetadas para evitar o colapso total do ente federado e, por consequência, que essas pessoas persistam sofrendo violações de direitos humanos. Inclusive, a situação particular vivida em Roraima é que faz surgir, no Brasil, uma discussão acerca da (im)possibilidade de fechamento da fronteira com o país vizinho, desencadeando discussões no âmbito do Poder Judiciário brasileiro, tal como aquelas que serão discutidas no ponto a seguir.

\title{
3 Os desdobramentos judiciais do influxo migratório "massivo" de venezuelanos ao Brasil
}

Vistos os motivos pelos quais os venezuelanos têm deixado o seu país de origem e os reflexos da entrada e acolhida desses migrantes pelo Estado brasileiro, volta-se, no presente ponto, à análise dos desdobramentos judiciais que ocorreram em 2018 em razão da falha do Brasil em suas estratégias para lidar com essa questão, particularmente a propositura de Ação Cível Originária n. ${ }^{\circ} 3121$, pelo estado de

\footnotetext{
20 Ressalta-se, todavia, a edição de outras MPs para auxiliar o Ministério da Defesa na atividade de acolhida, tal como a MP n. ${ }^{\circ} 823$ de 2018 , que liberou R\$ 190 milhões ao Ministério da Defesa (cuja vigência terminou em 09/07 sem a transformação em lei) e a MP n. 857 de 2018 , a qual transfere extraordinariamente mais R\$75.2 milhões para a realização de atividades de acolhida (BRASIL, 2018i; BRASIL, 2018j).

Cf. ESTEVES, 2018.

O centro de Boa Vista foi visitado, na data de 09/11/2018, por uma das autoras.

Cf. BRASIL, 2018n.
} 
Roraima, solicitando o fechamento da fronteira Brasil-Venezuela e o seu indeferimento por parte do Poder Judiciário.

\section{a. A propositura da Ação Cível Originária n. ${ }^{\circ} 3121$ do estado de Roraima (ACO n. ${ }^{\circ}$ 3121/RR)}

A entrada de um alto número de migrantes pelo município de Pacaraima (BRASIL, 2018a), onde se estima que a população esteja em torno de 16 mil habitantes (BRASIL, s/d), no estado com a menor densidade demográfica do país, ${ }^{24}$ causou muito alvoroço. A precária estrutura da cidade resultou em falta de auxílio e atendimento a esses migrantes, pois mesmo o acesso à moradia é escasso, já que há apenas um abrigo público e é exclusivo dos índios venezuelanos da etnia Warao (BRITO; CAMARGO, 2018). Isso sem contar a falta de segurança pública e a condição de miserabilidade em que chegam quase que a totalidade dos migrantes, denotando a falta de assistência estatal para lidar com essa situação, relegando essas pessoas à situação de rua e fome.

Em resposta ao cenário retratado, o governo de Roraima moveu, no dia 13 de abril de 2018, a Ação Cível Originária n. ${ }^{\circ} 3121$ no Supremo Tribunal Federal, na qual, em pedido de tutela provisória, postulou pelo fechamento temporário da fronteira do Brasil com a Venezuela, tal como já haviam feito Equador ${ }^{25} \mathrm{e}$ Peru. ${ }^{26} \mathrm{~A}$ parte autora pediu, ainda, que a Corte determinasse que a União atuasse efetivamente na área fronteiriça em questão, promovendo controle policial, de saúde e sanitário, e transferisse recursos adicionais para desonerar o estado dos custos que estaria suportando, especialmente com a educação e a saúde dos venezuelanos lá estabelecidos (STF, 2018, p. 8).

O referido instrumento, assim como a Ação Civil Pública regulada pela Lei Federal n. ${ }^{\circ} 7.347 / 85$, cuida de reprimir ou, se possível, prevenir danos ao meio ambiente, ao consumidor, aos bens e direitos de valor artístico, estético, histórico, turístico e paisagístico, por infração da ordem econômica, à ordem urbanística, à honra e à dignidade de grupos raciais, étnicos e religiosos, ao patrimônio público e social, e a qualquer outro interesse difuso ou coletivo, podendo resultar em condenação monetária ou no cumprimento de obrigação de fazer ou não fazer (BRASIL, 1985, Art. 1).

Conforme as regras de definição de competência, a ação deve ser proposta perante o foro do local do dano, isto é, havendo dano ambiental a um parque de conservação ecológica de determinado estado, o foro competente para a propositura da ação será o da capital desse mesmo estado. Já a Ação Cível Originária é cabível, portanto, para garantir um direito ou o cumprimento de uma obrigação civil, e é qualificada como originária porque sua competência tem origem no Supremo Tribunal Federal, que é a instância judiciária adequada para tratar de conflitos entre Estados estrangeiros, ou organismos internacionais, e a União, estados, Distrito Federal e territórios, e, ainda, litígios entre a União, os órgãos da administração indireta, o Distrito Federal e os estados membros, tal como o caso em comento.

Na Ação Cível Originária n. ${ }^{\circ} 3121 / R R$, o estado de Roraima afirma que a União está abstendo-se da observância ao chamado pacto federativo, o qual consiste no conjunto de dispositivos constitucionais que configuram a moldura jurídica, as obrigações financeiras, a arrecadação de recurso e os campos de atuação dos entes federados (União, estados e município), com regramentos sobre quem faz o que e por meio de qual fonte de arrecadação. Nesse viés, a requerente afirma que a União está violando o pacto ao permitir a entrada massiva de refugiados venezuelanos no país, haja vista o ente fronteiriço ser o menor

24 O estado de Roraima tem 2,02 habitantes por quilometro quadrado, sendo a menor densidade demográfica do Brasil (BRASIL, s/d).

25 Em 8 de agosto de 2018, o Equador declarou estado de emergência institucional devido ao alto número de venezuelanos ingressando no seu território. Dez dias depois, restringiu a entrada desses migrantes no Estado, exigindo a apresentação de passaporte - item até então desnecessário forte na possibilidade de utilização da cédula de identidade. A medida só foi suspensa uma semana depois, dia $24 / 08$, quando uma sentença anulou a medida executiva por considerá-la atentatória aos direitos humanos. Além disso, ordenou-se ao Ministério das Relações Exteriores do país que, em 45 dias, apresentasse um plano de contingência humanitário. Ademais, permitiu a formação de um "corredor humanitário", para que os cidadãos venezuelanos chegassem ao Peru (DW, 2018; ESPAÑA, 2017; CUBANET, 2018; REVISTA ISTO É, 2018).

26 O Peru foi o segundo país a fechar as fronteiras para os migrantes venezuelanos sem passaporte, apenas admitindo aqueles que possuem tal documento ou que requisitarem refúgio. A medida, aprovada em 25 de agosto de 2018 , foi seguida por uma declaração de emergência sanitária no norte do país três dias depois, com duração de 60 dias, com base no perigo iminente de prejuízo na saúde e saneamento dessas regiões pelo influxo massivo de migrantes. Somente em 05 de outubro é que a justiça derrubou a medida executiva que exigia o passaporte, restaurando os requisitos antigos, os quais são fruto de acordos firmados no âmbito da Unasul e Comunidade Andina (da qual a Venezuela não mais participa desde 2011) (AGENCE FRANCE-PRESSE, 2018; DW, 2018; G1, 2018c). 
e o mais carente estado Brasileiro e não dispor de recursos para sustentar os desequilíbrios decorrentes do fluxo migratório.

Assim, aspira que o STF determine à União (STF, 2018): (a) que adote uma atuação efetiva na área de fronteira Brasil/Venezuela, a fim de impedir que o fluxo imigratório desordenado produza efeitos devastadores à sociedade brasileira, especialmente no estado de Roraima, promovendo medidas administrativas nas áreas de controle policial, de saúde e de vigilância sanitária; (b) que transfira recursos adicionais para suprir os custos suportados pelo estado de Roraima, principalmente com a saúde e a educação dos venezuelanos estabelecidos em território roraimense; (c) que feche temporariamente a fronteira do país com a Venezuela, a fim de impedir que o fluxo imigratório desordenado produza efeitos avassaladores aos brasileiros e migrantes residentes em Roraima ou, ainda, que limite o ingresso de refugiados venezuelanos a uma quantidade compatível com a capacidade do Estado brasileiro de acolher e prover as necessidades básicas dos migrantes, até que sejam minimizados e corrigidos os impactos sociais e econômicos decorrentes dos milhares de migrantes que estão no estado de Roraima.

Ao cabo, destaca-se que a ação proposta reivindica que o Poder Judiciário assuma uma postura de ativismo judicial, pedindo que este não apenas tenha o controle, mas também dirija a prática de políticas públicas voltadas para melhorar a estruturação do fluxo migratório da região (STF, 2018).

\section{b. O posicionamento do Poder Judiciário em face da ACO n. ${ }^{\circ} 3121 / R R$ e os fundamentos jurídicos para o seu indeferimento}

O aprofundamento da crise político-econômica da Venezuela, que a cada dia sujeita mais e mais pessoas a condições de vulnerabilidade, resultou no reconhecimento do status de crise humanitária, conforme aponta o relatório do Acnur (2018) sobre o fluxo de venezuelanos. Nesse sentido, a relatora da ACO n. ${ }^{\circ} 3121 / R R$, ministra Rosa Weber, convocou audiência de conciliação, na qual esteve presente a governadora do estado de Roraima, Suely Campos, a advogada-geral da União, Grace Maria Fernandes Mendonça, e, também, representantes do Ministério Público Federal, da Defensoria Pública da União e demais amicus curiae. ${ }^{27}$

Na ocasião não houve conciliação, tendo a União e o Ministério Público Federal (MPF) se manifestado contrários ao pedido de fechamento de fronteira e a Advocacia-Geral da União registrado que os demais pleitos apresentados pelo estado dependem de deliberação de diversas esferas do governo federal, já que envolvem muitas pastas ministeriais, ${ }^{28} \mathrm{e}$, assim, nova audiência foi designada para o mês de agosto. Dessa forma, a manutenção do intenso fluxo migratório associada à precária condição de recepção no município de Pacaraima - somada, talvez, ao posicionamento político do governo roraimense, que buscava judicialmente pelo fechamento fronteiriço - acabou por alimentar a hostilidade com que alguns brasileiros estão tratando os venezuelanos que alcançam o País. ${ }^{29}$

Logo, em 05 de agosto, o juiz federal Helder Girão Barreto, da $1^{\text {a }}$ Vara Federal de Roraima, ordenou a suspensão da entrada de migrantes venezuelanos no Brasil pela fronteira entre os municípios de Pacaraima e Santa Elena de Uairén, em decisão judicial aos pedidos feitos pelo MPF e pela Defensoria Pública da União para suspender a aplicação do decreto da governadora, Suely Campos, que, em $01^{\circ}$ de agosto, entre outras determinações, condicionava a apresentação de passaporte válido pelos venezuelanos para que pudessem ser atendidos pelas redes de saúde e educação do estado, o que, na prática, os impedia de acessar os serviços públicos, já que muitos cruzam a fronteira sem quaisquer documentos (RORAIMA, 2018).

\footnotetext{
27 Em 14/05/2018, a ministra Rosa Weber deferiu o ingresso como amicus curiae na ACO n. ${ }^{\circ}$ 3121/RR da Defensoria Pública da União (evento 9), da Associação Direitos Humanos em Rede Conectas Direitos Humanos, do Instituto Migrações e Direitos Humanos (IMDH), do Centro de Direitos Humanos e Cidadania do Imigrante (CDHI)C e Pia Sociedade dos Missionários de São Paulo (eventos 14 e 39), também do município de Pacaraima/ RR (evento 32), da Sociedade de Defesa dos Índios Unidos do Norte de Roraima (SODIURR), da Aliança de Integração e Desenvolvimento das Comunidades Indígenas de Roraima (ALIDCIRR) e da Associação de Desenvolvimento dos Povos Indígenas Taurepangs do estado de Roraima (ADPITERR) (evento 41) (STF, 2018).

28 Audiência realizada em 18/05/2018, às 14 horas, na sala de audiências da Secretaria Judiciária do Supremo Tribunal Federal (STF, 2018).

29 Conforme se observa da notícia em que a casa onde viviam 31 venezuelanos é alvo de tentativa de explosão (FELIX, 2018).
} 
Por seu turno, a ministra Rosa Weber, em 06 de agosto, data agendada para audiência, indeferiu o pedido de fechamento temporário da fronteira com a Venezuela, que visava limitar o ingresso de refugiados venezuelanos no Brasil, indeferindo a tutela provisória da ACO n. ${ }^{\circ} 3121$, ajuizada pelo estado de Roraima contra a União. De pronto, a decisão rechaçou o pedido de ativismo judicial e amparou-se no artigo 84 , inciso VII, da Constituição Federal, para explicar que é de competência privativa do presidente da República a deliberação acerca das relações entre o Brasil e os estados vizinhos, tal como o caso em questão. ${ }^{30}$ No entanto, apesar da competência ser privativa do presidente no exercício da soberania do Estado, a relatora frisou que a discricionariedade assegurada ao chefe do Poder Executivo deve considerar os tratados internacionais adotados pelo Brasil e a legislação sobre a matéria.

Ainda sob o viés constitucional, fundamentou que, em respeito ao artigo $5^{\circ}$, inciso LIV da Constituição, ${ }^{31}$ a adoção de medidas que se ocupem de restringir migrações irregulares ameaça à privação de indivíduos não apenas do acesso ao território, mas do próprio acesso ao procedimento de obtenção de refúgio no Estado de destino, podendo, então, ofender à cláusula constitucional asseguradora do devido processo legal e resultar no descumprimento do dever de proteção assumido internacionalmente com o acolhimento humanitário.

No âmbito do direito internacional, a ministra suscitou a Convenção de Genebra sobre o Estatuto dos Refugiados de 1951 (BRASIL, 1990) e o seu Protocolo de 1967 (BRASIL, 1972), particularmente no tocante à impossibilidade de rechaço de pessoa - independentemente da sua origem ou do ano de sua saída do seu Estado de origem -, a qual possa sofrer violações de direitos humanos, direta e/ou indiretamente, quando do seu retorno ao local de origem. ${ }^{32}$

Na sequência, Rosa Weber também se apoiou na Declaração de Cartagena de 1984 (OEA, 1984), esta notadamente citada com base na abertura conceitual por ela introduzida, considerando "também como refugiados as pessoas que tenham fugido dos seus países porque a sua vida, segurança ou liberdade tenham sido ameaçadas pela violência generalizada" - situação facilmente encaixada no contexto venezuelano hodierno ${ }^{33}$-, bem como a Declaração de Brasília sobre a Proteção de Refugiados e Apátridas no Continente Americano (ACNUR, 2010), haja vista citar a necessidade de revitalizar-se programas como o das "fronteiras solidárias", o qual consiste na "facilitação do livre trânsito dos refugiados a terceiros países onde possam ter acesso a emprego remunerado e conseguir autossuficiência econômica" (REDIN, 2016, p. 8).

Por fim, mas não menos importante, cita, a ministra, o Acordo sobre Cooperação Sanitário Fronteiriça (BRASIL, 1991), formalizado em 1982 entre os governos do Brasil e da Venezuela, no qual os Estados se comprometem a não adotar medidas que impliquem o fechamento total de suas respectivas fronteiras - em que pese sujeitas a algumas exceções. ${ }^{34}$

Destacou, ainda, relativo à ordem jurídica infraconstitucional, que a medida de acolhimento humanitário imediato, prévio ao procedimento de análise e eventual deferimento formal de refúgio, inserido como princípio norteador na nova Lei de Migração $0^{35}$ da política migratória pátria, é de competência do Poder Executivo e deflui de todas as normas internacionais a que aderiu o Brasil. Ademais, a decisão da relatora apoiou-se em outras diretrizes da política migratória assumida pelo país, como o fortalecimento da integração econômica, política, social e cultural dos povos da América Latina, ${ }^{36}$ mediante constituição de espaços de cidadania e

30 Art. 84; "Compete privativamente ao Presidente da República: (...) VII - manter relações com Estados estrangeiros e acreditar seus representantes diplomáticos" (BRASIL, 2018p).

31 Art. $5^{\circ}$, LIV - LIV: "ninguém será privado da liberdade ou de seus bens sem o devido processo legal". (BRASIL, 2018p).

32 Trata-se do princípio do non-refoulement, pedra angular do Direito Internacional dos Direitos Humanos, previsto no art. 33 da Convenção de Genebra, cujo objetivo é evitar que a pessoa possa sofrer de violações diretas (causadas pelo Estado ou por pessoa sob seu controle/orientação - o que não necessariamente resta comprovado na Venezuela) ou indiretas (quando oriunda de uma omissão do Estado - o que seria especificamente o caso venezuelano). (BRASIL, 1990).

33 Defende Fernando Xavier que a citação dessa Declaração não teria sido uma escolha feliz da ministra, posição da qual discordamos. Isso porque, por mais que se trate de uma declaração e, logo, de uma Soft Law, esta categorização normativa não se dá ipso facto. Afinal, no contexto latinoamericano, esse documento foi largamente internalizado pelos Estados, não sendo possível dizer, com a devida vênia, que se trata de uma mera regra sugestiva - posição essa que se encontra demonstrada pela Corte Interamericana (XAVIER, 2018; CtIDH. 2014, p. 30 - nota n. 120).

34 Estas, por exemplo, podem ser apontadas no referido acordo entre Brasil e Venezuela, as quais apontam a impossibilidade de fechamento das fronteiras, com exceção a motivos de saúde pública, e desde que seguindo as normas administrativas internacionais para a realização desse procedimento, como previsto no artigo XVIII.

35 Art. $3^{\circ}$ : "A política migratória brasileira rege-se pelos seguintes princípios e diretrizes: (..) VI - acolhida humanitária" (BRASIL, 2017).

${ }^{36}$ Art. $3^{\circ},(\ldots)$ XIV: "fortalecimento da integração econômica, política, social e cultural dos povos da América Latina, mediante constituição de espaços de cidadania e de livre circulação de pessoas; XV - cooperação internacional com Estados de origem, de trânsito e de destino de movimentos migratórios, a fim de garantir efetiva proteção aos direitos humanos do migrante" (BRASIL, 2017). 
de livre circulação de pessoas, com vistas a garantir a efetiva proteção aos direitos humanos do migrante - isso sem olvidar do próprio art. 45, parágrafo único, o qual tece que "ninguém será impedido de ingressar no país por motivo de raça, religião, nacionalidade, pertinência a grupo social ou opinião política" (BRASIL, 2017, Art. 45, p.u).

Desse modo, não só o pedido de fechamento temporário da fronteira com a Venezuela foi indeferido, bem como a limitação da entrada de refugiados venezuelanos ao Brasil também restou afastada. Além disso, determinou-se que a decisão fosse imediatamente comunicada ao juízo da $1^{\text {a }}$ Vara Federal de Roraima, suspendendo cautelarmente, assim, o Decreto Estadual $n .^{\circ} 25.681$, de 2018 , que estabelecia regramentos que acabavam por restringir o acesso dos venezuelanos aos serviços públicos.

O não fechamento da fronteira, portanto, além de encontrar adequação constitucional ao respeitar a prevalência dos direitos humanos e efetivar o princípio da cooperação entre os povos para o progresso de todos ${ }^{37}$ reforça o compromisso do Estado brasileiro com o ordenamento jurídico interno e, também, no âmbito internacional, notadamente quando se tem a pessoa humana no centro do sistema jurídico global. Contudo, após a decisão da ministra do Supremo, a cidade roraimense, Pacaraima, registrou tumultos violentos entre brasileiros e venezuelanos, resultando na destruição de alguns acampamentos desses migrantes (BRANDÃO; OLIVEIRA, 2018). Em face do novo episódio, o governo federal enviou 120 homens da Força Nacional para reforçar a segurança do estado de Roraima.

Na sequência, a Advocacia-Geral da União (AGU) apresentou uma manifestação contrária ao pedido do governo de Roraima para fechamento temporário da fronteira entre Brasil e Venezuela (STF, 2018, pet. 54380). No documento entregue ao STF, a AGU argumenta que, além de ineficaz, o fechamento da fronteira é contrário à ordem jurídica nacional e internacional, uma vez que violaria tratados internacionais dos quais o Brasil é signatário, particularmente o Acordo sobre Cooperação Sanitária Fronteiriça, citado pela ministra relatora no STF, acerca da impossibilidade do fechamento total das fronteiras, ${ }^{38}$ como apontado supra.

A manifestação da AGU (STF, 2018, pet. 54380 - p. 15) concentrou-se em demonstrar que o Decreto Estadual $n .^{\circ} 25.681$, de $1^{\circ}$ de agosto de 2018 , de Roraima deve ser suspenso, pois a conduta da parte autora está enquadrada como ato atentatório à dignidade da Justiça, devendo ser aplicadas as sanções previstas no art. $77, \mathrm{VI}, \S \S 1^{\circ} \mathrm{e} 2^{\circ}$ do Código de Processo Civil. ${ }^{39}$ Ademais, reitera todos os argumentos do indeferimento ao pedido de fechamento de fronteira da decisão judicial proferida pela ministra Rosa Weber, que até o final do mês de novembro de 2018 está mantido.

\section{Conclusão}

De fato, a situação na fronteira brasileira com a Venezuela é desanimadora. Muitas pessoas vivem nas ruas e não têm emprego. Todavia grande parte delas não critica essa situação, afinal, elas têm alimento (sejam as refeições oferecidas nos abrigos, sejam no supermercado) e acesso à saúde e a medicamentos - o que está cada vez mais raro no seu país de origem. Logo, mesmo que a situação desses migrantes no Brasil possa ser classificada como desoladora para os padrões de direitos humanos pátrios, ela é melhor do que aquela encontrada na Venezuela, isto é, a de um país que está em total instabilidade.

Essa situação é fruto de diversas políticas governamentais de insucesso, as quais conduziram a Venezuela à decadência socioeconômica, e não se vislumbra no seu horizonte uma melhoria. Por isso,

Artigo 40: "A República Federativa do Brasil rege-se nas suas relações internacionais pelos seguintes princípios: (...) II - prevalência dos direitos humanos; (...) IX - cooperação entre os povos para o progresso da humanidade" (BRASIL, 2018p).

38 Artigo XVIII: "Os Governos do Brasil e da Venezuela comprometem-se a não adotar medidas de profilaxia internacional que impliquem o fechamento total de suas respectivas fronteiras e limitarão as medidas, quando for indispensável, á zona afetada. As medidas em tela só poderão ser dispostas pelas autoridades sanitárias nacionais de acordo com o Regulamento Sanitário Internacional, e serão notificadas imediatamente à Organização Pan-Americana da Saúde" (BRASIL, 1991).

39 Art. 77: "Além de outros previstos neste Código, são deveres das partes, de seus procuradores e de todos aqueles que de qualquer forma participem do processo: (...) VI - não praticar inovação ilegal no estado de fato de bem ou direito litigioso. § 1o Nas hipóteses dos incisos IV e VI, o juiz advertirá qualquer das pessoas mencionadas no caput de que sua conduta poderá ser punida como ato atentatório à dignidade da justiça. $\S 2$ 으 $A$ violação ao disposto nos incisos IV e VI constitui ato atentatório à dignidade da justiça, devendo o juiz, sem prejuízo das sanções criminais, civis e processuais cabíveis, aplicar ao responsável multa de até vinte por cento do valor da causa, de acordo com a gravidade da conduta" (BRASIL, 2015). 
a acentuação das vulnerabilidades é uma conseqüência lógica, terminando por afetar todos os países vizinhos. Mesmo que, ao longo dos anos, o Brasil esteja recebendo cada vez mais cidadãos venezuelanos, ele não é o Estado de destino preferido, muito em razão do idioma e da própria instabilidade institucional que perpassa o país. A preferência é por países hispano hablantes, particularmente Colômbia e Peru.

Ocorre que, se esses indivíduos buscarem o Brasil, este não pode rechaçá-los, tendo o dever de processar os pedidos de refúgio quando solicitados, haja vista ser esse um direito da pessoa, bem como analisar os pedidos de residência temporária à luz das normativas constitucionais e infraconstitucionais, as quais estão em constante aprimoramento no que tange à proteção do ser humano. Nesse viés, negar a entrada de venezuelanos através do fechamento da fronteira, como almeja ainda o estado de Roraima, não se faz coerente ou legalmente possível.

Por mais que falte estrutura nas localidades fronteiriças ou próxima a elas para a recepção de migrantes, realizar o fechamento da fronteira mostra-se um atentado contra a proteção da pessoa humana e sua dignidade - valor este insculpido não só na Constituição Federal, como também no centro do próprio sistema internacional desde 1945, com a edificação das Nações Unidas e de diversos documentos que foram editados sob os seus auspícios, como a Declaração Universal dos Direitos Humanos - hoje considerada uma regra consuetudinária, logo, vinculante - e a Convenção de Genebra de 1951 sobre o Estatuto dos Refugiados, para citar alguns.

Se existe uma omissão do Estado brasileiro no que diz respeito ao controle de entrada de migrantes e à própria proteção sanitária das fronteiras, deve o governo federal agir de modo a reverter essa situação, sem que, na sua concretização, o indivíduo seja afetado. Exatamente isso é o que se objetivou com a edição da MP n. ${ }^{\circ} 820$ e dos decretos que autorizaram explicitamente o uso das Forças Armadas para a garantia da lei e da ordem na região de fronteira: garantir os direitos humanos daqueles que buscam a proteção do Estado brasileiro, evitando-se, assim, uma dupla e contínua violação da sua dignidade. Claro que essa medida está sujeita a melhorias - os venezuelanos, em sua grande maioria, ainda estão em situação de hipervulnerabilidade e marginalização no Brasil. Outrossim, a correção dessas questões só se dará com a adoção de uma política migratória consistente, a qual já possui suas bases delineadas na nova Lei de Migração - em vigor há um ano apenas.

Por conseguinte, com base nos propósitos do presente escrito, tem-se que o Poder Judiciário agiu corretamente ao negar o pedido de fechamento de fronteira requisitado pelo estado de Roraima. Com certeza, este não seria o caminho a ser seguido consoante os mandamentos normativos internos e internacionais, como bem assinalou a ministra relatora Rosa Weber. Inclusive, esse é o entendimento que se vislumbra de situações análogas ocorridas no Equador e no Peru, onde as limitações de entrada também foram suspensas pelos respectivos Poderes Judiciários.

Por fim, cumpre salientar que o Estado brasileiro se submete à jurisdição da Corte Interamericana de Direitos Humanos, a qual tem se dedicado a discussões referentes ao tratamento de migrantes nos Estados partes da Organização dos Estados Americanos, deixando claro que os indivíduos não apenas têm o direito de migrar, como também os Estados têm o dever de respeitar os seus direitos basilares, tais como a não discriminação, a não devolução, a informação, o acesso efetivo à justiça, entre outros, sob a pena de ter que reparar integralmente o sujeito afetado. Logo, deve o Estado brasileiro continuar reciclando-se no que concerne ao acolhimento e à integração de migrantes na sociedade, para que suas práticas não sejam objeto de questionamento em tal foro e, quem sabe, possa se tornar um expoente no tratamento de migrantes na região e no globo.

\section{Referências}

AGENCE FRANCE-PRESSE. Equador abre corredor humanitário para venezuelanos rumo ao Peru. Revista Istoé, São Paulo, 24 ago. 2018a. Disponível em: https://istoe.com.br/venezuelanos-tentamentrar-no-peru-antes-de-novas-normas-migratorias/. Acesso em: 2 dez. 2018. 
AGENCE FRANCE-PRESSE. Peru fecha fronteira aos venezuelanos sem passaporte. O Globo, Lima, 25 ago. 2018b. Disponível em: https://oglobo.globo.com/mundo/peru-fecha-fronteira-aos-venezuelanossem-passaporte-23010843. Acesso em: 2 dez. 2018.

AGENCE FRANCE-PRESSE. Venezuelanos poderão entrar no Peru sem passaporte. G1, Rio de Janeiro, 5 out. 2018c. Disponível em: https://g1.globo.com/mundo/noticia/2018/10/05/venezuelanospoderao-entrar-no-peru-sem-passaporte.ghtml. Acesso em: 2 dez. 2018.

ALTO COMISSARIADO DAS NAÇÕES UNIDAS PARA OS REFUGIADOS. Declaração de Brasília sobre a proteção de refugiados e apátridas no continente americano. Brasília: ACNUR, 2010. Disponível em: https://www.acnur.org/fileadmin/Documentos/portugues/BDL/Declaracao_de_Brasilia_ sobre_a_Protecao_de_Refugiados_e_Apatridas_no_Continente_Americano.pdf. Acesso em: 1 dez. 2018.

ALTO COMISSARIADO DAS NAÇÕES UNIDAS PARA OS REFUGIADOS. Notas de orientação sobre o fluxo de venezuelanos. Genebra: ACNUR, 2018. Disponível em: https://www.refworld.org/cgi-bin/ texis/vtx/rwmain/opendocpdf.pdf?reldoc=y\&docid=5aa23fae4. Acesso em: 2 dez. 2018.

ARAÚJO, Carla; MONTEIRO, Tânia; RIBEIRO, Luci. Temer publica no Diário Oficial dois decretos e uma MP para tentar conter crise em Roraima. Estadão, Brasília, 15 fev. 2018. Disponível em: https:// internacional.estadao.com.br/noticias/geral,temer-assina-dois-decretos-e-uma-mp-para-tentar-contercrise-migratoria-em-roraima,70002190963. Acesso em: 2 dez. 2018.

BITTENCOURT, Rafael. Venezuelanos responderam por $53 \%$ dos pedidos de refúgio no Brasil. Valor Econômico, Brasília, 11 abr. 2018. Disponível em: https://www.valor.com.br/politica/5445913/ venezuelanos-responderam-por-53-dos-pedidos-de-refugio-no-brasil. Acesso em: 2 dez. 2018.

BRANDÃO, Inaê. RR decreta emergência na Saúde por causa da imigração de venezuelanos. G1 Roraima, Boa Vista, 7 dez. 2016. Disponível em: g1.globo.com/rr/roraima/noticia/2016/12/rr-decretaemergencia-na-saude-por-causa-da-imigracao-de-venezuelanos.html. Acesso em: 2 dez. 2018.

BRANDÃO, Inaê; OLIVEIRA, Valéria. Cidade de RR na fronteira com a Venezuela tem tumulto após assalto a comerciante. G1 Roraima, Boa Vista, 18 ago. 2018. Disponível em: https://g1.globo.com/ $\mathrm{rr} /$ roraima/noticia/2018/08/18/cidade-de-rr-na-fronteira-com-a-venezuela-tem-tumulto-apos-assalto-acomerciante.ghtml. Acesso em: 26 nov. 2018.

BRASIL. Casa Civil. Ajuda Humanitária Portaria agiliza regularização de imigrantes venezuelanos no Brasil. Brasília, 28 ago. 2018c. Disponível em: www.brasil.gov.br/noticias/seguranca-e-justica/2018/08/ portaria-agiliza-regularizacao-de-imigrantes-venezuelanos-no-brasil. Acesso em: 2 dez. 2018.

BRASIL. [Constituição (1988)]. Constituição da República Federativa do Brasil de 1988. Brasília: Presidência da República, [2018p]. Disponível em: www.planalto.gov.br/ccivil_03/Constituicao/ Constituicao.htm. Acesso em: 1 dez. 2018.

BRASIL. Decreto n. 50.215, de 25 de janeiro de 1961. Promulga a Convenção relativa ao Estatuto dos Refugiados. Brasília: Presidência da República, [1990]. Disponível em: www.planalto.gov.br/ccivil_03/ decreto/1950-1969/D50215.htm. Acesso em: 1 dez. 2018.

BRASIL. Decreto n. 9.285, de 15 de fevereiro de 2018. Reconhece a situação de vulnerabilidade decorrente de fluxo migratório provocado por crise humanitária na República Bolivariana da Venezuela. Brasília: Presidência da República, 2018h. Disponível em: http://www.planalto.gov.br/ccivil_03/_Ato20152018/2018/Decreto/D9285.htm. Acesso em: 2 dez. 2018.

BRASIL. Decreto n. 9.286, de 15 de fevereiro de 2018. Define a composição, as competências e as normas de funcionamento do Comitê Federal de Assistência Emergencial para acolhimento a pessoas em situação de vulnerabilidade decorrente de fluxo migratório provocado por crise humanitária. Brasília: Presidência da República, [2018o]. Disponível em: http://www.planalto.gov.br/ccivil_03/_ato20152018/2018/Decreto/D9286.htm. Acesso em: 2 dez. 2018.

BRASIL. Decreto n. 9.483, de 28 de agosto de 2018. Autoriza o emprego das Forças Armadas para a Garantia da Lei e da Ordem nas áreas especificadas, no Estado de Roraima. Brasília: Presidência da República, 2018k. Disponível em: portal.imprensanacional.gov.br/materia/-/asset_ 
publisher/Kujrw0TZC2Mb/content /id/38774484/do1-2018-08-29-decreto-n-9-483-de-28-de-agostode-2018-38774314. Acesso em: 2 dez. 2018.

BRASIL. Decreto n. 9.501, de 11 de setembro de 2018. Altera o Decreto $n^{\circ} 9.483$, de 28 de agosto de 2018, que autoriza o emprego das Forças Armadas para a Garantia da Lei e da Ordem nas áreas especificadas, no Estado de Roraima. Brasília: Presidência da República, 2018I. Disponível em: portal. imprensanacional.gov.br/materia/-/asset_publisher/Kujrw0TZC2Mb/content/ id/40549158/do1-2018-0912-decreto-n-9-501-de-11-de-setembro-de-2018-40549011. Acesso em: 2 dez. 2018.

BRASIL. Decreto n. 9.543, de 29 de outubro de 2018. Autoriza o emprego das Forças Armadas na Garantia da Lei e da Ordem, no Estado de Roraima, para a proteção das instalações e das atividades relacionadas ao acolhimento de refugiados. Brasília: Presidência da República, 2018m. Disponível em: www.imprensanacional.gov.br/materia/-/asset_publisher/Kujrw0TZC2Mb/content/ id/47744593. Acesso em: 2 dez. 2018.

BRASIL. Decreto $n^{\circ}$ 59, 14 de março de 1991. Promulga o Acordo sobre Cooperação Sanitária Fronteiriça entre o Governo da República Federativa do Brasil e o Governo da República da Venezuela. Brasília: Presidência da República, 1991. Disponível em: www.planalto.gov.br/ccivil_03/ decreto/1990-1994/D0059.htm. Acesso em: 1 dez. 2018.

BRASIL. Decreto $n^{\circ}$ 70.946, de 07 de agosto de 1972. Promulga o Protocolo sobre o Estatuto dos Refugiados. Brasília: Presidência da República, 1972. Disponível em: www.planalto.gov.br/ccivil_03/ decreto/1970-1979/D70946.htm. Acesso em: 1 dez. 2018.

BRASIL. Lei Federal 13.445, de 24 de maio de 2017. Institui a Lei de Migração. Brasília: Presidência da República, 2017. Disponível em: www.planalto.gov.br/ccivil_03/_Ato2015-2018/2017/Lei/L13445.htm. Acesso em: 2 dez. 2018.

BRASIL. Lei Federal n. 13.684, de 21 de junho de 2018. Dispõe sobre medidas de assistência emergencial para acolhimento a pessoas em situação de vulnerabilidade decorrente de fluxo migratório provocado por crise humanitária; e dá outras providências. Brasília: Presidência da República, $2018 \mathrm{e}$. Disponível em: www.planalto.gov.b r/ccivil_03/_ato2015-2018/2018/lei/L13684.htm. Acesso em: 2 dez. 2018

BRASIL. Lei Federal n.6.815, de 19 de agosto de 1980. Define a situação jurídica do estrangeiro no Brasil, cria o Conselho Nacional de Imigração. Brasília: Presidência da República, [2017]. Disponível em: www.planalto.gov.b r/ccivil_03/Leis/L6815.htm. Acesso em: 2 dez. 2018.

BRASIL. Lei Federal $\mathbf{n}^{0}$ 13.105, 16 de março de 2015. Código de Processo Civil. Brasília: Presidência da República, 2015. Disponível em: www.planalto.gov.br/ccivil_03/_Ato2015-2018/2015/Lei/L13105.htm. Acesso em: 1 dez. 2018.

BRASIL. Lei Federal $\mathbf{n}^{\circ}$ 7.347, de 24 de julho de 1985. Disciplina a ação civil pública de responsabilidade por danos causados ao meio-ambiente, ao consumidor, a bens e direitos de valor artístico, estético, histórico, turístico e paisagístico (VETADO) e dá outras providências. Brasília: Presidência da República, [1995]. Disponível em: www.planalto.gov.br/ccivil_03/leis/L7347orig.htm. Acesso em: 1 dez. 2018.

BRASIL. Medida Provisória n. 820 de 2018, de 15 de fevereiro de 2018. Dispõe sobre medidas de assistência emergencial para acolhimento a pessoas em situação de vulnerabilidade decorrente de fluxo migratório provocado por crise humanitária. Brasília: Presidência da República, 2018. Disponível em: http://www.planalto.gov.br/ccivil_03/_ato2015-2018/2018/Mpv/mpv820.htm. Acesso em: 2 dez. 2018.

BRASIL. Ministério da Defesa. Defesa viabiliza apoio a imigrantes venezuelanos em Roraima. Ministério da Defesa, Brasília, 13 mar. 2018i. Disponível em: https://www.defesa.gov.br/noticias/40604-defesaviabiliza-apoio-a-imigrantes-venezuelanos-em-roraima. Acesso em: 2 dez. 2018.

BRASIL. Ministério da Defesa. Noticiário do Exército, Brasília, 2018n. Disponível em: <www.eb.mil. $\mathrm{br} /$ web/noticias/noticiario-do-exercito?p_p_id=101_instance_mjag9 3KcunQI\&p_p_lifecycle=0\&p_p_ state=normal\&p_p_mode=view\&p_p_col_id=column-1\&p_p_col_count $=1 \& p \_r$ _p_564233524_ tag=operação+acolhida. Acesso em: 2 dez. 2018. 
BRASIL. Ministério da Justiça. Portaria Interministerial $n^{\circ}$ 9, de 14 de março de 2018. Dispõe sobre a concessão de autorização de residência ao imigrante que esteja em território brasileiro e seja nacional de país fronteiriço, onde não esteja em vigor o Acordo de Residência para Nacionais dos Estados Partes do Mercosul e países associados, a fim atender a interesses da política migratória nacional. Brasília: Ministério da Justiça, 2018d. Disponível em: https://lex.com.br/legis_27624738_portaria_ interministerial_n_9_de_14_de_marco_de_2018.aspx. Acesso em: 2 dez. 2018.

BRASIL. Presidência da República. Casa Civil. Polícia Federal atualiza dados sobre migração de venezuelanos. Casa Civil, Brasília, 5 set. 2018a. Disponível em: http://www.casacivil.gov.br/centralde-conteudos/noticias/2018/setembro/policia-federal-atualiza-dados-sobre-migracao-de-venezuelanos. Acesso em: 1 dez. 2018.

BRASIL. Senado Federal. Governo publica MP que destina R $\$ 75,2$ milhões para assistência a venezuelanos. Senado Notícias, Brasília, 21 nov. 2018j. Disponível em: http://www12.senado.leg. $\mathrm{br} /$ noticias/materias/2018/11/21/governo-publica-mp-que-destina-r-75-2-milhoes-para-assistencia-avenezuelanos. Acesso em: 2 dez. 2018.

BRASIL. Senado Federal. Senado aprova apoio emergencial a imigrantes. Senado Notícias, Brasília, 12 jun. 2018g. Disponível em: https://www12.senado.leg.br/noticias/materias/2018/06/12/senado-aprovaapoio-emergencial-a-imigrantes. Acesso em: 1 dez. 2018.

BRASIL. Supremo Tribunal Federal. Ação Cível Originária n. 3121/RR. Liminar indeferida. Publicada em 07/08/2018. Fluxo migratório misto. Venezuela-brasil. Situação de refúgio lato sensu. Conflito federativo.

Estado de Roraima. União. Fechamento de fronteira. Pedido de tutela antecipada. Indeferimento.

Relatora: Min. Rosa Weber, 13 de abril de 2018. Disponível em: http://portal.stf.jus.br/processos/ downloadPeca.asp?id=314927053\&ext=.pdf. Acesso em: 2 dez. de 2018.

BRITO, Débora; CAMARGO, Marcelo. Ambiente é recriado para imigrantes da etnia Warao da Venezuela: abrigo Janokoida busca integrar os indígenas com a comunidade. Agência Brasil-EBC, Brasília, 24 ago. 2018. Disponível em: http://agenciabrasil.ebc.com.br/direitos-humanos/noticia/2018-08/ ambiente-e-recriado-para-imigrantes-da-etnia-warao-da-venezuela. Acesso em: 26 nov. 2018.

CHADE, Jamil. Diretor da OMS alerta que crise na Venezuela pode causar surtos no Brasil. Estadão, Genebra, 8 mai. 2018. Disponível em: https://saude.estadao.com.br/noticias/geral,diretor-da-oms-alertaque-crise-na-venezuela-pode-causar-surtos-no-brasil,70002314320. Acesso em: 2 dez. 2018.

CORONIL, Fernando. EI Estado mágico: naturaleza, dinero y modernidad en Venezuela. Caracas: Ed. Alfa, 2013.

COSTA, Emily. Surto de sarampo importado da Venezuela faz Saúde de RR antecipar campanha de vacinação tríplice viral. G1 Roraima, Boa Vista, 5 mar. 2018a. Disponível em: https://g1.globo.com/ rr/ roraima/noticia/surto-de-sarampo-importado-da-venezuela-faz-saude-de-rr-antecipar-campanha-devacinacao-triplice-viral.ghtml. Acesso em: 2 dez. 2018.

COSTA, Emily. Conselho de Direitos Humanos critica 'acolhida humanitária militarizada' de venezuelanos em RR: 'é preocupante'. G1 Roraima, Boa Vista, 22 maio 2018b. Disponível em: https://g1 .globo.com/rr/ roraima/noticia/conselho-de-direitos-humanos-critica-acolhida-humanitaria-militarizada-de-venezuelanosem-rr-e-preocupante.ghtml. Acesso em: 2 dez. 2018.

COSTA, Emily. Mais de 75 mil venezuelanos pediram para se regularizar em Roraima entre 2015 e agosto de 2018, diz Casa Civil. G1 Roraima, Boa Vista, 6 set. 2018c. Disponível em: https://g1.globo. $\mathrm{com} / \mathrm{rr} /$ roraima/noticia/2018/09/06/mais-de-75-mil-venezuelanos-pediram-para-se-regularizar-em-rrentre-2015-e-agosto-de-2018-diz-casa-civil.ghtml. Acesso em: 2 dez. 2018.

CORTE INTERAMERICANA DE DIREITOS HUMANOS. Parecer Consultivo OC-21/14, de 19 de agosto de 2014. Direitos e garantias de crianças no contexto da migração /ou em necessidade de proteção internacional. Costa Rica: CtIDH, 2014. Disponível em: www.corteidh.or.cr/docs/opiniones/ seriea_21_por.pdf. Acesso em: 1 dez. 2018. 
CUBANET. Ecuador anula requisito de pasaporte para venezolanos que entran a su territorio. Cubanet, Coral Gables-FL, 25 ago. 2018. Disponível em: https://www.cubanet.org/noticias/ecuador-anula-requisitode-pasaporte-para-venezolanos/. Acesso em: 2 dez. 2018.

CURY, Anay. Governo Chávez melhorou PIB, mas aumentou dependência do petróleo. G1, São Paulo, 5 mar. 2013. Disponível em: g1.globo.com/economia/noticia/2013/03/governo-chavez-melhorou-pib-masaumentou-dependencia-do-petroleo.html. Acesso em: 1 dez. 2018.

DELFIM, Rodrigo Borges. Nova portaria permite residência temporária de venezuelanos no Brasil.

Migra Mundo, São Paulo, 20 mar. 2018. Disponível em: https://migramundo.com/nova-portaria-permiteresidencia-temporaria-de-venezuelanos-no-brasil/. Acesso em: 1 dez. 2018.

DEUTSCHE WELLE. Equador declara estado de emergência por chegada de venezuelanos. DW, [Bonn], 9 ago. 2018. Disponível em: https://p.dw.com/p/32tsl. Acesso em: 2 dez. 2018.

DEUTSCHE WELLE. Perú declara emergencia sanitaria por migración venezolana. DW, [Bonn], 28 ago. 2018. Disponível em: https://p.dw.com/p/33url. Acesso em: 2 dez. 2018.

ESPAÑA N., Luis Pedro. Encuesta sobre Condiciones de Vida en Venezuela. Pobreza. IIES-UCAB.

Febrero 2016. Caracas: Fundación Bengoa para la Alimentación y Nutrición, 2017. Disponível em: https:// www.fundacionbengoa.org/noticias/2017/images/ENCOVI-2016-Pobreza.pdf. Acesso em: 26 nov. 2018.

ESTEVES, Hugo Campitelli Z. O decreto de garantia de lei e ordem em Roraima e a afronta ao princípio da subsidiariedade. Migalhas, Ribeirão Preto, 3 dez. 2018. Disponível em: https://www.migalhas.com.br/ dePeso/16,MI286684,21048-O+decreto+de+garantia+de+lei+e+ordem+em+Roraima +e+a+afronta+ao. Acesso em: 2 dez. 2018.

FAGUNDES, Álvaro. Quintuplica total de venezuelanos em escolas de Roraima, e já faltam vagas. Folha de São Paulo, São Paulo, 22 abr. 2018. Disponível em: https://www1.folha.uol.com.br/ mundo/2018/04/ quintuplica-total-de-venezuelanos-em-escolas-de-roraima-e-ja-faltam-vagas.shtml. Acesso em: 2 dez. 2018.

FELIX, Jackson. Vídeo mostra homem causando explosão com combustível em casa onde vivem 31 venezuelanos em Boa Vista. G1 Roraima, Boa Vista, 9 fev. 2018. Disponível em: https://g1.globo.com/ $\mathrm{rr} /$ roraima/noticia/video-mostra-homem-causando-explosao-com-gasolina-em-casa-onde-vivem-31venezuelanos-em-boa-vista.ghtml. Acesso em: 1 dez. 2018.

FELIX, Jackson; COSTA, Emily. Venezuelanas em RR dizem que foram obrigadas a trocar sexo por comida. G1 Roraima, Boa Vista, 26 ago. 2016. Disponível em: g1.globo.com/rr/roraima/noticia/ 2016/08/ venezuelanas-em-rr-dizem-que-foram-obrigadas-trocar-sexo-por-comida.html. Acesso em: 2 dez. 2018.

FOLHA DE BOA VISTA. Regularização no Brasil: venezuelanos buscam PF para evitar clandestinidade. Folha de Boa Vista, Boa Vista, 23 fev. 2018. Disponível em: https://www.folhabv.com.br/noticia/ Venezuelanos-buscam-PF-para-evitar-clandestinidade/37123. Acesso em: 1 dez. 2018.

FOLHA DE SÃO PAULO. Cerca de 10 mil venezuelanos pediram residência no Brasil em 50 dias, diz PF. Folha de São Paulo, São Paulo, 22 maio 2018. Disponível em: https://www1.folha.uol.com.br/ mundo/2018/05/cerca-de-10-mil-venezuelanos-pediram-residencia-no-brasil-em-50-dias-diz-pf.shtml. Acesso em: 1 dez. 2018.

G1 RORAIMA. 54\% dos venezuelanos que entraram no Brasil por RR desde 2017 já deixaram o país, diz ministro. G1 Roraima, Boa Vista, 17 jul. 2018a. Disponível em: https://g1.globo.com/rr/roraima/ noticia/54-dos-venezuelanos-que-entraram-no-brasil-por-rr-desde-2017-ja-deixaram-o-pais-diz-ministro. ghtml. Acesso em: 1 dez 2018.

G1. Herdeiro de Chávez, Maduro é eleito na Venezuela: rival não reconhece. G1, São Paulo, 15 abr. 2013. Disponível em: g1.globo.com/mundo/hugo-chavez/noticia/2013/04/herdeiro-politico-de-chavezmaduro-e-eleito-presidente-da-venezuela.html. Acesso em: 1 dez. 2018.

G1 RORAIMA. Justiça retira taxas para imigrantes venezuelanos que pedem residência temporária no Brasil. G1 Roraima, Boa Vista, 1 ago. 2017. Disponível em: https://g1.globo.com/rr/roraima/noticia/ justica-retira-taxas-para-imigrantes-venezuelanos-que-pedem-residencia-temporaria-no-brasil.ghtml. Acesso em: 2 dez. 2018. 
G1 RORAIMA. PF deporta 200 venezuelanos por entrada e permanência ilegal em RR. G1 Roraima, Boa Vista, I set. 2016. Disponível em: http://g1.globo.com/rr/roraima/noticia/2016/09/pf-'deporta-200venezuelanos-por-entrada-e-permanencia-ilegal-em-rr.html. Acesso em: 2 dez. 2018.

G1 RORAIMA. Prefeitura decreta emergência social em Boa Vista em razão da imigração de venezuelanos. G1 Roraima, Boa Vista, 23 fev. 2018c. Disponível em: https://g1.globo.com/rr/roraima/ noticia/prefeitura-decreta-emergencia-social-em-boa-vista-em-razao-da-imigracao-de-venezuelanos. ghtml. Acesso em: 2 dez. 2018.

GORTÁZAR, Naiara Galarraga. Êxodo venezuelano: onde estão esses $7 \%$ de venezuelanos forçados a fugir. EI País, Madrid, 30 ago. 2018. Disponível em: https://brasil.elpais.com/brasil/2018/ 08/26/ internacional/1535307553_501641.html. Acesso em: 1 dez. 2018.

INSTITUTO BRASILEIRO DE GEOGRAFIA E ESTATÍSTICA. Projeção da População 2018: número de habitantes do país deve parar de crescer em 2047. [Rio de Janeiro]: IBGE, 25 jul 2018b.

Disponível em: https://agenciadenoticias.ibge.gov.br/agencia-sala-de-imprensa/2013-agencia-de-noticias/ releases/21837-projecao-da-populacao-2018-numero-de-habitantes-do-pais-deve-parar-de-crescerem-2047. Acesso em: 26 nov. 2018.

INSTITUTO BRASILEIRO DE GEOGRAFIA E ESTATÍSTICA. Panorama Pacaraima. [Rio de Janeiro]: IBGE. Disponível em: https://cidades.ibge.gov.br/brasil/rr/pacaraima/panorama. Acesso em: 26 nov. 2018.

JORNAL NACIONAL. Roraima prorroga por seis meses situação de emergência social. G1, Rio de Janeiro, 23 ago. 2018. Disponível em: https://g1.globo.com/jornal-nacional/noticia/2018/08/23/roraimaprorroga-por-seis-meses-situacao-de-emergencia-social.ghtml. Acesso em: 2 dez. 2018.

MAISONNAVE, Fabiano. Explodem pedidos de refúgio de venezuelanos em Manaus. Folha de São Paulo, Manaus, 24 jun. 2018. Disponível em: https://www1.folha.uol.com.br/mundo/2018/06/explodempedidos-de-refugio-de-venezuelanos-em-manaus.shtml. Acesso em: 2 dez. 2018.

MARTINS, Helena. Brasil tem mais de 86 mil pedidos de refúgio em tramitação: venezuelanos lideram. Agência Brasil - EBC, Brasília, 11 abr. 2018. Disponível em: agenciabrasil.ebc.com.br/direitos-humanos/ noticia/2018-04/brasil-tem-mais-de-86-mil-pedidos-de-refugio-em-tramitacao. Acesso em: 2 dez. 2018.

MARTINS, Helena. CNDH critica "militarização" do atendimento a venezuelanos em Roraima. Agência Brasil-EBC, Brasília, 21 mai. 2018. Disponível em: agenciabrasil.ebc.com.br/direitos-humanos/ noticia/2018-05/cndh-critica-militarizacao-do-atendimento-venezuelanos-em-roraima. Acesso em: 2 dez. 2018.

MENDONÇA, Heloísa. Êxodo venezuelano: Roraima à flor da pele. El País, Boa Vista, 23 ago. 2018. Disponível em: https://brasil.elpais.com/brasil/2018/08/22/politica/1534965762_180606.html. Acesso em: 1 dez. 2018.

O GLOBO. Meio milhão de venezuelanos já fugiram para o Equador este ano, diz ONU. O Globo, Rio de Janeiro, 10 ago. 2018. Disponível em: https://oglobo.globo.com/mundo/meio-milhao-de-venezuelanos-jafugiram-para-equador-este-ano-diz-onu-22966492. Acesso em: 1 dez. 2018.

ORGANIZAÇÃO DOS ESTADOS AMERICANOS. Declaração de Cartagena. Cartagena: OEA, 1984. Disponivel em: https://www.acnur.org/fileadmin/Documentos/portugues/BD_Legal/Instrumentos_ Internacionais/Declaracao_de_Cartagena.pdf. Acesso em: 1 dez. 2018.

PARAGUASSU, Lisandra. MP vai aumentar presença do Exército na fronteira com Venezuela. Revista Exame, Brasília, 4 fev. 2018. Disponível em: https://exame.abril.com.br/brasil/mp-vai-aumentarpresenca-do-exercito-na-fronteira-com-venezuela/. Acesso em: 2 dez. 2018.

PASSARINHO, Nathalia. Brasil recebe apenas $2 \%$ dos 2,3 milhões de venezuelanos expulsos pela crise. BBC News Brasil, São Paulo, 21 ago. 2018. Disponível em: https://www.bbc.com/portuguese/ brasil-45251779. Acesso em: 1 dez. 2018.

PEREIRA, André Paulo. A imigração venezuelana em Roraima e o risco da explosão demográfica. Estadão, São Paulo, 20 ago. 2018. Disponível em: https://politica. estadao.com.br/blogs/fausto-macedo/ a-imigracao-venezuelana-em-roraima-e-o-risco-da-explosao-demografica/. Acesso em: 1 dez 2018. 
REDIN, Giuliana. Direito humano de imigrar e os desafios para a construção de uma política nacional para imigrantes e refugiados. In: REDIN, Giuliana; SALDANHA, Jania Maria L.; SILVA, Maria Beatriz O. (org.). Direitos emergentes na sociedade global. Santa Maria-RS: Ed. UFSM, 2016. p. 1-13

RIBEIRO, Vicente Neves da Silva. Venezuela Bolivariana: disputas pelo controle do petróleo em perspectiva. In: SCHURSTER, Karl; ARAUJO, Rafael Pinheiró (org.). A Era Chávez e a Venezuela no tempo presente. Rio de Janeiro: Autografia: Edupe, 2015. p. 257-269.

RORAIMA. Decreto Estadual n. 25.681, de 1 de agosto de 2018. Decreta atuação especial das forças de segurança pública e demais agentes públicos do Estado de Roraima em decorrência do fluxo migratório de estrangeiros em território do Estado de Roraima e dá outras providências. Boa Vista: Governo do Estado, 2018. Disponível em: https://www.conectas.org/wp/wp-content/uploads/2018/08/ selection.pdf. Acesso em: 1 dez. 2018.

SCHURSTER, Karl; ARAUJO, Rafael. A Venezuela entre 1989 e 2013: crises, rupturas e continuidades. In: SCHURSTER, Karl; ARAUJO, Rafael Pinheiró (org.). A Era Chávez e a Venezuela no tempo presente. Rio de Janeiro: Autografia: Edupe, 2015. p. 15-45.

SOUZA, André Luiz Coelho Farias de. Instabilidade Política e Democracia na Venezuela - de Carlos Andrés Pérez a Hugo Chávez. In: SCHURSTER, Karl; ARAUJO, Rafael Pinheiró (org.). A Era Chávez e a Venezuela no tempo presente. Rio de Janeiro: Autografia: Edupe, 2015. p. 47-66.

SPAÑA, Sara. Ecuador restringirá la entrada de venezolanos por la llegada de 4.000 al día. EI País, Guayaquill, 18 ago. 2018. Disponível em: https://elpais.com/internacional/2018/08/17/ actualidad/ 1534500798_245140.html. Acesso em: 2 dez. de 2018.

TOLEDO, Marcelo. Deportações de venezuelanos na fronteira com Roraima crescem $824 \%$. Folha de São Paulo, Pacaraima, 23 nov. 2016. Disponível em: https://www1.folha.uol.com.br/ mundo/2016/11/1834629-deportacoes-de-venezuelanos-na-fronteira-com-roraima-crescem-824.shtml. Acesso em: 2 dez. 2018.

VEJA. Pedidos de refúgio de venezuelanos no Brasil dobram em cinco meses. Veja, São Paulo, 16 out. 2018. Disponível em: https://veja.abril.com.br/mundo/pedidos-de-refugio-de-venezuelanos-no-brasildobram-em-5-meses/. Acesso em: 1 dez. 2018.

VERA, Leonardo. ¿Cómo explicar la catástrofe econômica venezoelana? Revista de Nueva Sociedad, Buenos Aires, n. 274, p. 83-96, mar./abr. 2018. Disponível em: https://www.nuso.org/revista/274/ venezuela-el-ocaso-de-la-revolucion/. Acesso em: 17 jun. 2020.

VIEIRA, Ana Luisa. Falta de oportunidades marca realidade de venezuelanos no Brasil. R7, São Paulo, 14 abr. 2018. Disponível em: https://noticias.r7.com/inter nacional/falta-de-oportunidades-marcarealidade-de-venezuelanos-no-brasil-14042018. Acesso em: 1 dez. 2018.

VIEIRA, Ana Luisa. Pedidos de refúgio de venezuelanos crescem 226\% em um ano. R7, São Paulo, 19 jun. 2018. Disponível em: https://noticias.r7.com/inter nacional/pedidos-de-refugio-de-venezuelanoscrescem-226-em-um-ano-21062018. Acesso em: 1 dez. 2018.

XAVIER, Fernando César Costa. Sobre as (im)possibilidades jurídicas do fechamento da fronteira. Consultor Jurídico, São Paulo, 22 ago. 2018. Disponível em: https://www.conjur.com.br/2018-ago-22/ fernando-xavier-questoes-juridicas-fechamento-fronteira?imprimir=1. Acesso em: 1 dez. 2018.

Recebido em: 02/04/2020

Aprovado em: 02/05/2020 